\title{
Impact of company capital structure on of its value growth estimation
}

\author{
Oksana Pirogova ${ }^{1, *}$, and Vladimir Plotnikov ${ }^{2}$ \\ ${ }^{1}$ Saint Petersburg State Polytechnic University, Industrial Management Institute, Economy and Trade, Graduate School of \\ Commodity and Service, Saint-Petersburg, Russia \\ ${ }^{2}$ Saint Petersburg State University of Economics, Department of General Economic Theory, Saint-Petersburg, Russia
}

\begin{abstract}
The article analyses the influence of the use of commercial loans on the free cash flow generation based on cost-based management concept. It is shown that the use of commercial credit instead of the usual short-term lending reduces the force of the operational lever. On the other hand, when calculating the economic added value indicators, the use of conventional lending leads to the increase in the economic added value and as a result of the higher cost of growth. This effect is associated with the redistribution of cash outflows and changes in the level of risk for the stakeholders of the enterprise.
\end{abstract}

\section{Introduction}

Development of new approaches to the development of enterprises can not manage without a thorough analysis of the relationships that arise between the company and stakeholders in the course of business and the implementation of strategic management plans.

Nowadays more and more widely known gets cost management concept (Value Based Management VBM). The concept of value-based (in the broader interpretation - the concept of value-based management) requires that an enterprise as an open social and economic system in its development should strive to maximize its value [1 - 4]. Despite the many advantages, the introduction of the concept of value in the work of modern domestic enterprises comes into serious difficulties. The difficulties of implementation of the concept in trade relate primarily to the following aspects $[1,2]$ :

- Developed nowadays methodological approaches and economic models are primarily intended for large enterprises, however, for small and medium enterprises, the concept is not very applicable;

- Indicators to measure the value of a company or its growth have different shapes and are often not comparable;

- Most of the indicators to measure the growth of the cost of a commercial product, contained in the methodology of the application a number of patented and protected know-how, which are known only to the manufacturer. In addition, the introduction of such products requires significant organizational and financial resources, including the adaptation of the product for a specific company and its licensing support.
Despite these difficulties, the cost-based approach to this stage of economics development is the most progressive approach that allows to manage the planning and evaluation of the enterprise on the basis of an integrated indicator - the cost. It is obvious that the sustainable development of enterprises can only be achieved on the basis of the successful implementation of the basic ideas of cost-based approach.

Development of common views and approaches to the management to ensure the fundamental value growth requires the development of models and methods to comprehensively link parameters such economic activities of commercial enterprise, the cost structure, structure and sources of funding, the level of economic risk. An important aspect of cost-based approach is the recognition of paid sources of capital, which had previously belonged to the free (eg, equity) or shareware (eg accounts payable). It should be noted that the question of taking into account the various sources of funding in the capital structure in assessing the value of the moment is controversial [2, 4, 5]. The main controversy related to the problem of accounting accounts payable.

\section{Sources of venture capital}

Sources of financing business activities are divided into two main groups: companies' own funds and borrowed funds. Almost all enterprises in varying degrees, use both sources of funding, however, its volume and structure are due to many factors such as enterprise size, growth dynamics, history of development, and others. For many businesses, especially retail feature is the extensive use of commercial credit to finance current operations. Commercial loans used to finance 
inventories and other elements of current assets. Many of the successful functioning enterprises have negative indicators of their own working capital, which is defined as the difference between current operating assets and liabilities, excluding loans and credits [5].

Moreover, in the structure of liabilities of modern retail enterprises accounts payable in the form of a commercial loan takes an important place. The following Table. 1 provides information on the capital structure of the largest domestic retail chains $[6,7,8,9]$.

Table. 1 shows that, even in large retail chains, which in size can be compared with the average level of corporations and have access to enough cheap credit resources, the share of accounts payable is an average of $20-35 \%$. For smaller commercial enterprises, such as the district consumer society, large stores, etc., the proportion of accounts payable may be even higher. Thus, the accounts payable appears essential element of equity trading businesses. Without the use of commercial credit traders it would be difficult to ensure high rates of economic activity and acceptable growth rate.

Table 1. Capital Structure of retail networks of the Russian Federation for 2015.

\begin{tabular}{|l|l|l|l|l|}
\hline $\begin{array}{l}\text { Structure } \\
\text { capital }\end{array}$ & $\begin{array}{l}\text { LLC Lenta, } \\
\text { ths. Rub. }\end{array}$ & $\begin{array}{l}\text { OKey LLC, } \\
\text { ths. Rub. }\end{array}$ & $\begin{array}{l}\text { PJSC } \\
\text { Magnit, } \\
\text { ths. Rub. }\end{array}$ & $\begin{array}{l}\text { X5, } \\
\text { ths. Rub. }\end{array}$ \\
\hline $\begin{array}{l}\text { Equity and } \\
\text { liabilities }\end{array}$ & 168485373 & 63420152 & 404192973 & 402115000 \\
\hline $\begin{array}{l}\text { Own funds and } \\
\text { others, equal } \\
\text { to own }\end{array}$ & 34145908 & 13328975 & 165140596 & 104718000 \\
\hline fixed liabilities & 74178051 & 11494273 & 59481188 & 101545000 \\
\hline $\begin{array}{l}\text { current } \\
\text { liabilities }\end{array}$ & 60161414 & 38596904 & 166642595 & 195852000 \\
\hline $\begin{array}{l}\text { Accounts } \\
\text { payable }\end{array}$ & 49012520 & 27918597 & 88372216 & 195852000 \\
\hline $\begin{array}{l}\text { In\% of the } \\
\text { capital }\end{array}$ & $29.09 \%$ & $44.02 \%$ & $21.86 \%$ & $48.71 \%$ \\
\hline
\end{tabular}

According to many authors $[1,2,3]$ accounts payable should not be taken into account when considering the weighted average cost of capital of the enterprise. However, this approach is the situation when a significant part of the enterprise working capital needs to be excluded from the analysis, and therefore should not be considered when determining the cost drivers.

One would agree with the authors of works only to the ex-tent that it is often this type of capital is adopted as shareware and can not count. However, the existence of accounts receivable of this size has a significant impact on the distribution of risks between stakeholders competing for free cash flow enterprise.

Thus, at the present stage of commercial credit being one of the most important sources of finance for enterprises, can have a significant influence on the formation and distribution of free cash flow, as well as the redistribution of financial risks between the stakeholders of the enterprise.

Short-term payables - capital's structure element of the enterprise. Analysis of short-term debt should be carried out in accordance with the structure of accounts payable. In accordance with the accounting rules are divided into short-term liabilities [5]:
- Short-term borrowings (with maturities of less than one year)

- Payables and short-term creditor obligations;

- Payable to participants (founders by income payments)

- Revenue of the future periods;

- Reserves for future expenses;

- Other short-term liabilities.

As can be seen, accounts payable is an element of shortterm debt. In terms of value concepts for commercial enterprises significant first and second elements are represented. Short-term borrowings in accordance with the cost-based approach are taken into account in the average cost of capital (WACC) $[1,3,4]$.

The very payables (short-term credit liabilities) is also not uniform in structure and includes the following main elements [5]:

- Payable to suppliers and contractors - the amount owed to suppliers and contractors for delivered and not paid for tangible assets (work performed and services rendered);

- Debt to the staff of the organization - the Organization's debt to workers on wages;

- Debts to the state budget funds - the amount of debt on insurance payments, contributions for compulsory pension insurance, etc ;

- Debt to budget - debt company for all types of payments to the budget;

- Advances received - advance payments received by the organization for the upcoming delivery of goods (works, services);

- Debts to other creditors - debt to insurance companies for property insurance and workers' organizations; debt to the accountable persons; unpaid and not listed penalties (fines, penalties).

For commercial enterprises it is common when the debts to suppliers and contractors amounts to $80-95 \%$ of the total ac-counts receivable. Such amounts receivable on settlements with suppliers due to the widespread use of commercial credit in the implementation of operations. Commercial loans in accordance with the Civil Code is in our case in the form of deferred payment or installment [10]. The use of commercial credit due to the difference in the duration of the buyer's and supplier's production and financial cycles.

In the analysis of the trade capital of the enterprise from the point of view of cost-based approach to the fore issues come such elements of capital like cost (ie the cost of raising capital), as well as the risk that generates some form of capital to the enterprise and the creditor.

\section{Methods of assessment of payables' attraction cost}

It is well known that the cost of individual items in accounts payable is different. So payable to personnel, the state budget funds, tax arrears are actually virtually free sources, as this are temporary funds, which were formed as a result of activity of the enterprise, but not paid due to deadline hasn't already come. However, the proportion of these elements in the structure of accounts payable of the trade enterprise is not great.

With debts to suppliers and contractors it is more complicated. Traditionally, financial analysis, it was 
believed that this type of payables forms shareware borrowed funds. In the future, with the development and introduction of cost-based approach, it became clear that the gratuity of this element is rather conventional.

Many authors suggest to estimate the payment for accounts payable, depending on the size of the potential discounts, which can get a buyer, paying for the goods delivered earlier than proposed in the supply agreement. [5] This means that the supplier in the event of payment delay increases the cost of the delivered goods. The greater the delay - the greater the margin, or vice versa, when paying for goods in a short period of time the buyer receives a discount on goods. As a rule, this discount is tied to the size of bank interest rate on shortterm loans.

In [5] proposed the following formula for estimating the value of payables to suppliers:

$$
k_{x p}=\frac{d}{100-d} \times \frac{360}{t-k} 100 \%
$$

where $d$ - discount, which can be obtained by paying the goods within days, $\%$;

$t$ - postponement of payment of the goods provided by the supplier, days;

$k_{c r}$ - product payment term in the case of discount days.

The formula (1) consists of two elements, which reflect the relative discount and the term of its provision, which allows to bring the cost of the source of funds to the standard value.

Based on the above, the weighted average cost of capital of commercial enterprise in mind the high homogeneity of accounts payable can be determined as follows:

$$
W A C C=k_{e} w_{e}+(1-n)\left(k_{d} w_{d}+k_{x p} w_{k p}\right),
$$

where $w_{e}, w_{d}, w_{c r}$ - the cost of equity, debt capital and accounts payable respectively.

$k_{e}, k_{d}, k_{c r}$ - share in the total capital structure of equity, debt capital and accounts payable respectively.

$n$ - income tax rate.

However, the account payable in the assessment of the cost of trading company is not limited to the calculation of the weighted average cost of capital. The fact that emerging hidden charges for the use of commercial credit impact on other economic indicators such as profits from the sale, as well as operational and dual levers.

It is important to note that cash flow in the form of a payment for a commercial loan, which is obtained by vendors, there is at the stage of repayment obligations for delivered goods to suppliers. Thus, the fee for the use of this type of capital is inherently (implicitly) included in these payments. [11] The mechanism of the hidden cash outflow as a fee for the use of trade credit is demonstrated in Figure 1. In addition, payment of the commercial value of the loan takes place before payment of the basic interest on trading business' debt, as well as the maturity of the enterprise cost. Therefore, commercial loans, affecting the amount of profit from the sale, also affects the strength of the operating and the conjugate lever.

\section{Evaluation of the impact of commercial credit on the strength of the operating and financial leverage}

To assess the impact of commercial credit will take a number of assumptions, to assess the impact of commercial credit:

1. When using commercial credit at the price per unit of output the value of the potential discounts is added, which can get a commercial enterprise from the supplier, i.e. increases turnover at purchase prices.

2. If you use a commercial loan commercial enterprise does not increase the sales volume and value of retail turnover due to competition in the market. The increase in the retail price of the goods immediately lead to lower sales volumes.

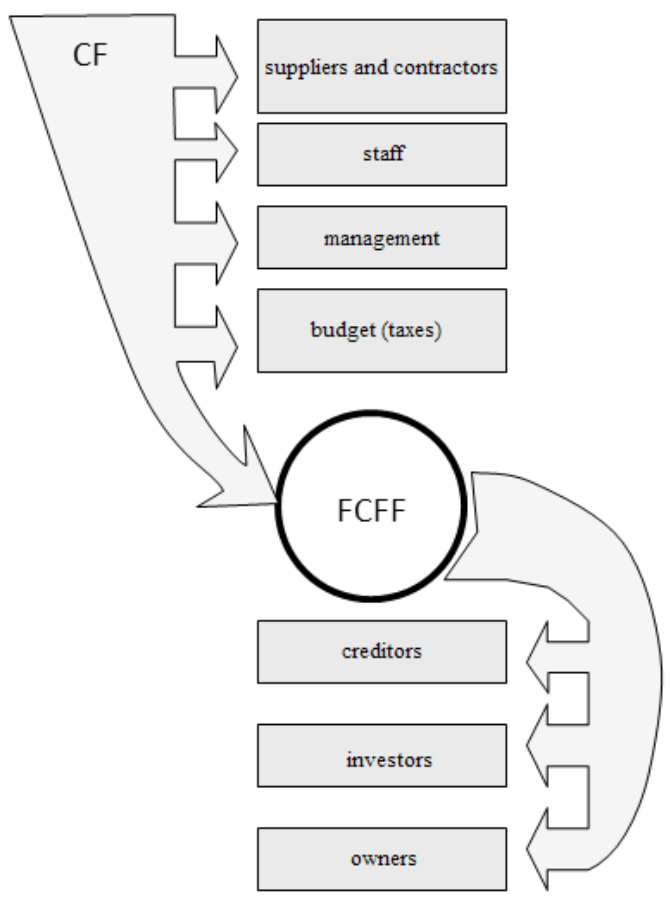

Fig. 1. Scheme of the distribution of company's cash flow.

In $[11,12]$ have shown that by comparing the dual forces of the lever based on commercial loans and excluding them() can be obtained the following expression:

$$
\begin{aligned}
& J_{c p}-J_{c p}^{\prime}=\frac{E B I T+F C}{E B I T-I}-\frac{E B I T^{\prime}+F C}{E B I T^{\prime}-I}= \\
& =\frac{E B I T+F C}{E B I T-I}-\frac{E B I T-T_{p y} \cdot Y_{c \kappa}+F C}{E B I T-I-T_{p u} \cdot Y_{c \kappa}}
\end{aligned}
$$

where EBIT - earnings before interest and taxes (adjusted profit on sales), excluding commercial loans; $E B I T^{\prime}$ - earnings before interest and taxes (adjusted profit from sales) from the register of commercial credit; $T_{r c}-$ turnover at retail prices;

$y_{s k}$ - discounts level per one ruble turnover at retail prices;

$F C$ - fixed costs at a given time interval of the enterprise; 
$I$ - interest on the loan.

It can be shown that this indicator is positive, the sign of the indicator depends on the value of the numerator of the expression (3), which is calculated by the formula:

$$
(F C+I) \times\left(T_{p \psi} \cdot Y_{c k}\right)
$$

This expression indicates that the value of the dual arm, calculated taking into account of a commercial loan should be less than when commercial credit is not included and accepted as payables.

The following Table 2 shows the dual lever calculations performed on data for the year 2015 of LLC "Lenta". The calculations were carried out based on the basic formula for determining the operational and financial leverage, as the ratio of the growth rates of key performance indicators for the reporting year (from sales revenue, gross profit, sales profit, net profit).

Table 2. Calculation of the dual arm with and without taking into account the commercial loan according to the activity.

\begin{tabular}{|l|l|l|}
\hline \multirow{2}{*}{\multicolumn{1}{|c|}{ Parameter }} & \multicolumn{2}{|c|}{$\begin{array}{c}\text { Excluding commercial } \\
\text { loans }\end{array}$} \\
\cline { 2 - 4 } & \multicolumn{1}{|c|}{$\mathbf{2 0 1 5}$} & \multicolumn{1}{|c|}{$\mathbf{2 0 1 4}$} \\
\hline Revenues, ths. Rub. & 288201963 & 220337828 \\
\hline Gross profit, ths. Rub. & 69519265 & 55730544 \\
\hline $\begin{array}{l}\text { Selling, general and administrative } \\
\text { expenses, ths. Rub. }\end{array}$ & 49696179 & 39334077 \\
\hline Operating profit, ths. Rub. & 19823086 & 16396467 \\
\hline Interest on loans, ths. rub. & 11958615 & 6782822 \\
\hline Adjusted pre-tax profit, ths. Rub. & 8881322 & 7699325 \\
\hline Adjusted net pr ibyl, ths. Rub. & 6291576.8 & 6159460 \\
\hline revenue growth rate & 0,308 & \\
\hline The growth rate of gross profit & 0,247 & \\
\hline The growth rate of profit on sales & 0,209 & \\
\hline The growth rate of the adjusted net profit & 0,0214 & \\
\hline The impact of operating leverage & 0,845 & \\
\hline The impact of financial leverage & 0,103 & \\
\hline The strength of the impact of the dual arm & 0,087 & \\
\hline Revenues, ths. Rub. & 288201963 & 220337828 \\
\hline Gross profit, ths. Rub. & 76416207 & 59810907 \\
\hline Selling, general and administrative \\
expenses, ths. Rub. & 49696179 & 39334077 \\
\hline Operating profit, ths. Rub. & 26720028 & 20476830 \\
\hline Interest on loans, ths. rub. & 18855557 & 10863185 \\
\hline Adjusted pre-tax profit, ths. Rub. & 8881322 & 7699325 \\
\hline Adjusted net pr ibyl, ths. Rub. & 6291576.8 & 6159460 \\
\hline revenue growth rate & 0,308 & \\
\hline The growth rate of gross profit & 0,278 & \\
\hline The growth rate of profit on sales & 0,305 & \\
\hline The growth rate of the adjusted net profit & 0,0214 & \\
\hline The impact of operating leverage & 1,098 & \\
\hline The impact of financial leverage & 0,070 & \\
\hline
\end{tabular}

Thus, it is clear that if, instead of accounts payable, the company would use the normal short-term loan, the strength of the impact of operating leverage has increased from 0,845 to 1,098 , but the impact of the financial strength and the dual levers - decreased from 0.103 to 0.070 and 0.087 to 0.077 respectively.

This change is explained by the fact that when using a conventional loan the cash outflow occurs at the stage of payment of the loan, and in the case of accounts payable outflow occurs at the stage of the calculation with suppliers.

This factor can be used in the planning of the company: in the conditions of intensive growth of trade turnover widest use of accounts payable is possible, it will provide profit growth and other indicators of a higher rate. At the same time, in terms of sales fall more appropriate is the use of short-term loans instead of short-term debt. This will provide a slower drop in profits and other indicators of the outcome of the enterprise.

\section{Conclusion}

In assessing the activity of the enterprise is an important factor to attract valuation of accounts payable. An adequate account of the cost of accounts payable as a result of the refusal of purchased goods' discounts to evaluate its contribution to the profits of the enterprise and the flexibility to man-age the pace of profit growth depends on the economic situation.

Another important aspect that requires further investigation - in case of changing of credit conditions changes the value of the weighted average cost of capital, the value of the invested capital and adjusted earnings before tax. This in turn leads to changes in the economic added value.

The research is financed by the Government task of Minis-try of education and science of the Russian Federation № 26.3546.2017/PCH "Development fundamentals of analysis and prediction of structural and dynamic parameters of the regional economy are based on the integration of the Russian and world experience of management of territorial development and modern scientific doctrines".

\section{References}

1. T.V. Teplova, HSE (2000)

2. M.V. Kudina (FORUM, INFRA-M, 2010)

3. F. Modigliani (Delo, 1999)

4. T. Copeland, T. Kohler, J. Murin (Moscow, 1999)

5. V.V. Kovalev, Prospect (2014)

6. https://www.edisclosure.ru/portal/files.aspx?id=9679-\&type $=3$

7. https://www.x5.ru/ru

8. http://www.dixygroup.ru

9. http://www.lenta.com

10. RF Civil Code (2014)

11. O.E. Pirogova, Bulletin of St. Petersburg State University of Economics, 6 (2014)

12. O.E. Pirogova, Proceedings of the St. Petersburg State University of Economics, 2 (2014) 